Environment Conservation Journal 16 (SE) 151-159, 2015

ISSN 0972-3099 (Print) 2278-5124 (Online)

Abstracted and Indexed

\title{
Russia's energy weapon as a tool against the expansion of NATO to the East
}

\author{
Pesaran Ghader. Iman; M.A, Jalalli*. Reza, Khosravi. MuhammadAli
}

Received:20.08.2015

Revised:25.08.2015

Accepted:30.09.2015

\begin{abstract}
After the Soviet collapse, the US-led NATO actions, in Eastern Europe and Central Asia has led to confrontation between Russia and the West in the region. Russia considers these actions a threat to its national security, reducing its power and influence and restrict its economic relations with its buffer zones. Moscow adopting policies such as anti-missile defense shield in Eastern Europe, leaving the CFE Treaty, creation of the CSTO and the use of energy as a practical weapon has withstand against the West. The country is the main supplier of the natural gas required for Europe and Eurasia, and is trying to run away the NATO from its red lines, use the it advantage to threat the newly independent republics of Europe Union by gas cut off and energy sanctions. The use of energy as a threatening tool by Russia has become a procedure to carry out its policies, which leads to a mistrust against the Russia and the countries are turning to other suppliers of the natural gas. Given the fact that the sale of energy is the main revenues of Russia, it seems, this threat will put Russia's into economic and political damage. The above mentioned topics, is the subject of this research.
\end{abstract}

Keywords:Russia Federation, NATO, Europe Union, Central Asia and the Caucasus, energy security. Introduction

With the collapse of the Soviet Union, it was again a new way to launch the Cold War. thought that the US-Soviet competition has ended and existing conflict and competition between them is replaced by cooperation, but after a while, the optimism gone dead and a new era of confrontation began between the two countries. This confrontation, however, is not as it was in the past, but indicate the formation of a new conflict and competition between the two countries. Since Russia is the heir of a superpower against the US, so of all the tools and resources in order to restore its former power benefit. This goal has triggered a new round of confrontation and competition between Russia and the United States (Aghaei et al. 2010: 29-31).In this situation another Cold War referred to as the new Cold War is forming which is due to the US-led NATO activities in the center of Eurasia and the Middle East that has led to color revolutions in Kazakhstan, Georgia and frequent change of power in Ukraine (Mirfakhraei, 2007: 90). The expansion of NATO to the East is geopolitical mistake of the West, which has led to strong opposition of Moscow and the efforts of Russia to unite with China, Iran and possibly Iraq, Author's Address

Faculty of political science, Azad University Tehran Central Branch, Tehran, Iran. Admission of the Baltic states into NATO would be a direct threat to the heart of Russia and Ukraine is the most important of them (Cohen, 2008: 325). Now Russia today, compared with the former Soviet Union, is in position of political, economic and military weakness and is trying to use Russia's energy strategy in the Vision 2020 document, to partially restore its missing (Zarei Hadak, 2012:131). In the Ukraine 2014 crisis this issue is clearly noticeable. Europe Union, one of the key client of the world's energy, especially natural gas, ensures the highest level of its gas from the Russian Federation due to insufficient resources. With the resumption of crisis in Ukraine and Crimea accession to the Russian Federation, the tension between the West and the East and has increased and with economic sanctions Russia, the West is trying to push the country out of its position and Russia, has threatened to boycott energy particularly for the EU Europe. The study objectives of this research is the interests of Russia and the United States in Central Asia and Russia's energy policy, in opposition to NATO's expansion to the East.

Method of this research is descriptive - analytical. This article seeks to answer the question of what role energy plays in the confrontation politics of

Copyright by ASEA

All rights of reproduction in any form reserved 
Ghader et al.

Russian Federation against NATO expansion to the East. The hypothesis is that it seems that Russia is using energy as a political tool in addition to the economic reconstruction the country, as a deterrent to prevent the expansion of NATO to the East. To better understand the issue we continue to discuss energy security and discuss opposition of the Russia to NATO's policies and its countermeasures Russia against NATO's actions.

\section{Concept of Energy Security}

The concept of energy security was first introduced into the international relations theories by Copenhagen school at the beginning of the $90 \mathrm{~s}$, and has changed the traditional framework of analysis of security and enumerates new definitions of security including military threats as well as four other types of threats (political, economic, social and environmental). In the theoretical framework of the school, adequate and stable supply of energy for the country's economics is vital for the well-being of the country as the fundamental values (Terriff $\&$ Drift, 1998, 137). There is no consistent definition of energy security. It is clear that energy security is a multifaceted issue and various stakeholders look at it, each from their own perspective. Supply, demand, oil industry and the environment are considered as different aspects of energy security (Mazreati, 2007, 72). Energy security includes a wide range of definitions, some of them are only a means to make fuel, some of it involving environmental quality and social and competitive markets, and to other categories requires new research for it (Soovakoul, 2012,36).

\section{Definitions of Energy Security}

Here we consider the main definition of energy security-Energy Research Center of Asia - Pacific: the ability of an economy to ensure the supply of energy resources in a sustainable way and over time at the price level that does not adversely affect the economic performance of the economy. This definition includes four elements: availability, accessibility, acceptability and affordability.Europe Commission: physical availability of energy products on the market price payable for all consumers without interruption.International Atomic Energy Agency: Assured supply of fuels and imported energy, self-driving technologies, as well as protection against the stop of supply, including protection against price volatility, encouraging a variety of technologies and resources, reducing the threat to neighboring states or absorption of them, fostering efficient markets and improving environmental sustainability.

IAEA: access to adequate, affordable and reliable fuels and energy services, including the availability of resources, to reduce dependency on imports, reducing pressure on the environment, the competition of efficient market, reliance on domestic sources of environmentally clean, affordable and distributed fairly energy services.The energy security term refers to a continuous supply of energy at reasonable prices. Those who use this term are looking to reduce the geopolitical, economic, technical, environmental and psychological threats of the energy markets. But the purpose of applying this word to this issue by political observers is that, firstly there must be a easy and without risk access to the world's oil and gas resources. Secondly, these resources have reasonable diversity in terms of geographical area, and the supplier countries should have a long term stable government (Maleki, 2007:206).For energy consumers, energy security is in fact nothing more than ensuring that energy would be available at a reasonable price at any given time and is always accessible without interruption.But from the perspective of suppliers, energy security is defined as security for energy demand as it cost a lot for them to product the energy. Because otherwise the providers should tolerate a lot of costs because of the delay in their investment. Additionally, the oil companies that have an important role in energy security, have a lot of attention to the profitability of their own activities.

Low profit margins have led to low investment in downstream and upstream activities by this company, which ultimately has a negative effect on energy security.It is noteworthy that although the oil and gas and other commercial fuels has vital role in the primary energy mix and energy security mainly refers to them,But the role renewable energy and energy in energy security in the coming years cannot be ignored in the current situation (Mazreati, 2007: 72-73).Energy security is ensuring of the country's ability for sustainable access to energy, continuous distribution of energy resources and diversify its supply. The energy sources should be geographically diverse having multiple routes and transmission and supply of gas and oil be from the locations that their governments have stability. 
Security of energy supply could cause big industrial states to include war even in the circle of their options. The energy has an important role in national security of the countries and is vital to supply economic power (Kolaee, 2011, 33).

\section{The elements of energy security}

According to Jonathan K.Layne the first deputy assistant secretary of energy of the United States in international energy policy, the energy security consists of four elements: availability, reliability, affordability, sustainability.

Availability: it refers to the relative independence and diversity of fuels and energy services. Ensure the availability to some extent dependent on providing "adequate and uninterrupted supply" and to minimize dependence on imported fuel. Related aspects of the availability, is diversification or preventing vandalism and attacks on critical infrastructure such as power plants, pipelines, dams and transmission and distribution networks to make their services to be provided. Diversity encompasses at least three dimensions. Diversification of resources, diversify and diversify local suppliers (Soovakoul, 2012,50).Churchill said: "The security and reliability of oil supply just depends on the diversity and the variety in achieving ". His basic principle of energy security can be defined as: "diversify of supply sources and routes of access"; diversification of energy resources is one of the most important guarantees of energy security and supply of energy is a vital fact (Kolaee, 2011: 32).

Affordability: is not just the low prices that people can give for energy services, but encompasses both the price stability and equitable access to energy services. When volatility is high the prudent fuel prices investment planning is difficult for suppliers (Soovakoul, 2012:50).

Productivity: is associated with the better and greater use of energy efficient equipment and behavioral changes. Energy efficiency provides the, cost-effective way of energy consumption to perform a specific job (for example, lighting the environment, transmission or heating) by minimizing the number of units of energy required for every unit of energy. Energy efficiency could include alternative sources of the fuel, changing habits and preferences, or the mix of goods and services such as to bring about lower demand for energy.
Administration: has emphasized the importance of stability or therefore, viability. This means ensuring that energy management system are acceptable for the community, the consumption rate of renewable sources does not exceed the rate of reproduction, environmental pollution and declining capacity of ecosystems does not exceed the absorption and pollution digestion and non-renewable resources be depleted with a same rate equivalent to reproduction of the renewable resources (ibid: 51).

Position of the energy in the Foreign policy of the countries

With the increasing economic dependence on hydrocarbon energy sources and competition over resources, it is quite natural the energy sources, energy corridors, consumer markets, energy trading, energy technology have found a great credit. Foreign policy of the countries and its relation with energy may be outlined in one of two modes below:

\section{Energy is a target for foreign policy}

Today, some countries are highly sought excellence in the global economy and due to the great influence of industrial and post-industrial countries of the issue of energy supply we are witnessing, the growing importance of energy, competition for energy and resources more effectively and maintaining excellence.An example we can refer to the United States, one of the important motivations US in attacking Iraq was oil, it seems that Washington's aim in Iraq crisis is the energy war with the Kremlin, Beijing, OPEC and the EU's Europe as well as seeking its own goals, it is because America's economic system is an energybased economy.

\section{Energy as a tool to achieve goals}

Today, energy is not a commodity, but a political tool that gathers the scholars and political experts of any country together and forces the governments to take any action for the maintenance or achieving. The countries with energy driven policy, take a considerable degrees of their decision according to the support of energy (Pasandideh, 2011, 92-93).

\section{Goals and interests of the West to intervene in Central Asia and Caucasus}

- Ability to control Russia, China and Iran, according to the geo-strategic position in Central Asia and the Caucasus; 


\section{Ghader et al.}

- Geopolitical importance of the region to fight extremism and terrorism in America long after the September 11 attacks;

- Vast energy resources of the region and greater control over resources; (Vaezi, 2007, 284).

- The protection of territorial integrity and political independence of the republics of the South Caucasus and help them to not be under pressure and bribery of Russia or Iran,

- Strengthening energy security through diversification of energy resources and the transfer of the Caspian Sea (Ebrahimi and Muhammadi, 2011, 6)

- Access to regional markets and expand its business

- Maintaining the status quo and strengthen the institutions of the region in line with its long-term goals;

- Support the expansion of Turkish influence;

- Strengthen security relations with countries in the region;

- Long-term presence in the region.

According Brzezinski in his book "A strategy for Eurasia", The presence of the USA in Eurasia and Georgia is not only oil or the fight against terrorism but the large-scale long-term goal is to enter the backyard of Russia in the region to prevent the formation of contracts and military alliances between the countries such as Iran, Russia and China and other Central Asian governments (Vaezi, 2009, 123).

Russia targets in the surrounding area, including Central Asia and the Caucasus-Control ethnic and religious uprising and preventing it from spreading into Russia just for internal security,

- The defense of Russia against the possible attacks of the world powers from the south,

- Preventing the influence of Asian countries,

- Preserve the economic benefits with the access to ports and roads,

- Preventing access of foreign powers in the regions where they may be used to threaten Russia,

- Maintaining the main military bases,

- Gradual discovery of information within the Commonwealth countries in the region.

- Prevent the emergence of any threat or the formation of political

- military groups along the borders of the former Soviet Union against the interests of Russia
- Seek to shape the broader geopolitical space of the former Soviet Union in accordance with the interests of Russia,

- Particular concern of Moscow about the rights of 25 million Russian-speaking and Russian citizens outside of the Russian Federation living in the other 14 former Soviet republics (Bowker\& Ross, 2000,341).

- The transit of energy resources of the Russia to the world markets via pipelines taking Russian oil and gas.

- Strengthening its position as one of the main providers of economic and technological needs of these countries and prevent their integration with Western structures;

- Preservation of the remaining monopoly of the Soviet-era in the region preserving their dependence on Russia

- The use of primary resources and raw materials in the region;

- The transit of goods and products to the Northern Europe region, especially for republics that have no way to open waters;

- Use of regional routes for trade relations with Iran and South Asia;

- Maintain the market of the region to supply part of the economic and trade requirements of the region (Vaezi, 2009, 111).

After the collapse of the Soviet Union, the US abandoned policy of containment of the Soviet Union immediately and turned to the policy of "expropriation" of the new Russia in the South Caucasus. Then US leaders decided to push back Russia from the region. Containing Russia needs to prevent the domination of Russia in the South Caucasus and Central Asia, in order to weaken Russian geopolitical, and even geo-economic situation in addition to control and demands of the former weaken Russia (Ebraham and Muhammadi, 2011, 14).

The reasons for Russia's opposition to the expansion of the West to the East

Expansion as the concept to threat the Russia's security

Russia, considers the NATO expansion as a threat against its national security and to reduce the authority of Russia in the international system, the 
elimination of buffer zones of Russia's and inattention to this great country.

Expansion of NATO in order to reduce the authority of Russia in the international system

After the collapse of the Soviet Union, Moscow lost its superpower in the international system, but Russia inherited the Soviet Union's conventional and nuclear weapons, Although Russia primarily is not a first rank international economic and military power, but is not a weak military country. Russians believe that any expansion to the East and to Russia is harmful for the country.

\section{Loss of buffer zones}

The Baltic republics and near abroad, have a high geopolitical and geo-strategic importance for Russia. The main reason is that these countries are considered as buffer zone against NATO expansion to the East Russia. On the other hand, Russia considers the expansion of NATO to Eastern Europe as a paved way for expansion into the Baltic countries and the near abroad republics, for this reason, has strongly opposed NATO expansion. White Russia, Belarus, Ukraine, Georgia, Azerbaijan and Armenia are among the Baltic Republics with a great importance for Russia (Haghshenas and Bauer, 2011, 13).

\section{The importance of buffer zones for Russia}

First, these countries were part of the Soviet Union and Russia is still willing to continue its influence on this countries. Second, Russia, consider the stability and security in these countries essential for the security and stability of Russia and is willing to continue its influence upon these countries. Third, Moscow is concerned about US influence in Europe which is against the interests of Russia.

\section{The policy of the Russian opposition against the} spread of West to the East

In the case of these policies Russia's opposition to the deployment of US missile defense project in Eastern Europe could be pointed out as a cooperation or threat. On the other hand Russia has suspended its membership in the CFE alliance (Mirfakhraei:2013, 154-160) and making a breaking barrier through the formation of CSTO Collective Security Treaty Organization, including Belarus, Armenia, Kazakhstan, Kyrgyzstan and Tajikistan to as a Russian version of NATO. However, under the Charter of the Organization , regional and medium-range goals such as combating international terrorism, religious extremism, drug trafficking and weapons businesses is the biggest concern, but the main goal is that Russia wants to control and deal with the possible developments of NATO to the East (Raquel, 2009: 12). Another strategy of Russia, is the politic of influence in Eurasia and consolidation of military and economic security in the CIS and the use of regional ethnic divisions. Lastly we can mention the energy weapon of Russia as a tool against the NATO and Europe which will be discussed in the following:

\section{Potential of Russia}

Russia as the largest producer of gas and at the same time as the geographically closest to Europe, provides a large supply of Europe gas. According to statistics published by BP in 2014, Russia's share of the world's gas reserves is $16.8 \%$ which is allocated the second rank after Iran (BP, 2015, 2326). The international sanctions of Iran, the obstacles such as opposition from Russia and the United States, followed by structural and technological weakness of the country has prevented Iran to have access to the EU market (Behboudi\& others, 2014).

The unrivaled Russia position is due to these factors:

- Large size and geographic location of it;

- The level of technology and significant potential for the discovery and extraction of oil and gas resources;

- Having the largest and most diversified network of export, transfer and transit of energy in Europe and Asia (Ebrahimi, 2004, 231).

\section{Europe's dependence on Russian gas}

According to official statistics of British National Oil Company in 2015 ,republics of the former Soviet Union and Europe has total gas consumption of $13.1 \%$ and $17.1 \%$ of the world overall consumption respectively. Now Europe's energy security depends heavily on Russia. Russia supplies half of natural gas and $30 \%$ of the Europe oil. Meanwhile, consumers in Eastern Europe even more of their Russian gas. Natural gas demand in Europe is increasing due to the replacement of coal and oil with natural gas. According to the forecasts contained Europe Commission Green Paper in 2006, by 2030, Europe needs to fossil fuel imports will increase from $50 \%$ to $70 \%$.

\section{5}

Environment Conservation Journal 
Ghader et al.

\section{Russia's energy policy}

In addition to maintaining the territorial integrity and sovereignty of the Russian Federation and its 89 constituent region and considering the country as a major power in the international system that has been emphasized in Russian foreign policy documents (Bowker\& Ross, 2000,341). In 2004, an economic model has been proposed by Putin government. This model is named (rational) and is implemented by the Putin government. Experts believe that this is a new type of state capitalism, which is run by the Russian government, including the governmental ownership especially of the oil industry which has expanded by theexpropriation of oil company Yukos and the acquisition of Sib by Gazprom.Russia has extended its control beyond its territory over the pipelines networks, ports, infrastructure and other energy assets in Central Asia and Eastern Europe and by increasing the price of energy from these countries has stepped to strengthen the its foreign policy. In cases where the surrounding countries have sold their energy to non-Russian companies, the energy of the country have been sanctioned. Countries in the region fear that Russia interfere in their internal affairs with this method. The administration officials of Bush and Obama, has criticized Russia for using energy as a political weapon. This document includes the energy market and the policies that helps the country to increase its international power. The title of this document is the "Russian 2020 Energy Strategy" which is a revised and complete version of the "Strategy toward 2010", which was published in 1995. This document includes strategic plans for oil and gas and to some extent, coal and hydroelectric energy (Ramazanadeh, 2010, 46). Russia's energy strategy, includes energy policy goals with regard to foreign countries, a better understanding of the global energy market, maximizing the possibility of exporting Russian energy, focusing on cooperation with Central Asian countries, ensuring equal access to finance for the Russian companies, technologies and foreign market.

\section{Russia's energy weapon}

Russia has tried to use various factors, including energy, for the reconstruction of the economic infrastructure and enhancing its position as a major power in international policies. Putin using an authoritarian policies, has intensified the government control over public and private oil and gas companies and the government has become as their economic policy maker. The goal of Russia for use of energy as a short-term foreign policy and energy security tool is to restore its influence in former Soviet republics and the countries of Central and Eastern Europe and reverse the movement of further integration with Western structures and NATO and in the long run weaken the influence ofAmerica is the continent of Europe.Kremlin administrations can be a balance weight to control energy resources and transmission lines in Eurasia and transforming this country into an exclusive source of energy supply in Europe and as the heart of West economy. This policy could affect the security of Europe in the long term (ZareiHadek, 2012,131). Russia's actions to take political security advantages out of energy to deal with the policy of NATO expansion to the East can be traced from two angles:The first angle, refers to the countries in the region, which are in Russia's near abroad, incidentally, dependent on energy imports from the country. Ukraine is an specific country in this regard, both in terms of the most willing country to enter the political-security structures of the West, especially NATO, and has the greatest dependence on energy imports from Russia, as well as obtain a large income from the transit of Russian gas to Europe. It is because, Ukraine supplies 51 percent of its gas and 86.6 percent of its oil from Russia. To eliminate this dependence, there is no alternative supplier.In the new logic of Russia, West-oriented country and that have obvious desire for membership in Western institutions, especially NATO, cannot benefit from its energy subsidies. Second, due to $80 \%$ of Russia gas export through to Ukraine to Europe, KF has a considerable transit revenue that is essential for the survival of the firms in the country.

The second angle is the dependence of Western Europe on import of oil and gas from Russia. Since the energy fluctuations have a direct impact on the economic development of European countries that import oil and gas, they prefer not to strain their relationship with Russia for NATO expansion to the East, which is an issue that the Russian elite, in particular, Putin is well aware of it; so that Germany, France and Italy are against the policy of NATO expansion to the East and the European and consider it as an American themes and subordinated 
to the interests and concerns of this country (Mirfakhraei, 2013,171-172).Basically, the gas war between Russia and Eastern Europe, is not reflecting changes in Russian policy on energy, but from 90 s the country is strengthening its foreign and security policy towards neighboring countries using this tool. In the early 90s, Moscow has cut its energy exports as to prevent the independency of the Baltic countries. In the 1993 after the request for the Baltic countries for the withdrawal of Russian troops from these countries, Russia again used this weapons.In 1993 and 1994 the country's gas exports to Ukraine were reduced to put pressure on Ukraine to fleet and give more freedom for Russia Navy in the Black Sea and give more freedom to Russian companies to influence the country's oil facilities. Energy war between Russia and Belarus in the early days of 2007, for the price of exporting gas, as well as Russia's move to cut gas deliveries to Ukraine in early 2006, and the threats to cut off gas in the years 2014 and 2015 following the domestic developments and turning to the West, was a political tool toward the geopolitical objectives, which caused an alarm to Europe as 80 percent of Russian gas to Europe passes through the country (ZareiHadek, 2012, 131).

Thomas Friedman, author of The Times believes that disputes between Russia and Europe over energy issues, start a new cold war in Europe again after the collapse of the Berlin Wall, is divided. He quotes José Joof author of "superpower: the temptation of empire like of the United States," writes that the influence of Russia in Western Europe through pipelines, has a greater impact than the country's long-range missiles (ZareiHadek, 2012.132 -131). Russian tries to implement energy strategy through a series of tactics. These tactics can be described as follows:

Involving demand: Russia is trying to sign longterm bilateral and multilateral contracts with individual European countries rather than a EU Union to form a separate deal with customers at different prices (Koolaee, 2011, 36).

Involving supply: the second tactics of Russia, is to monopolize gas supplies to consolidate their control over the strategic energy infrastructure, particularly in Europe and the Eurasian pipelines.

Russian Game: Russia have taken the "Russian Game" several times against Europe. In accordance with the "Russian Game", the owner of the energy source cuts of the energy supply in the most difficult conditions to consumers. In such a situation, most countries are forced to accept the bid of the new price, otherwise it would be removed from the list of business partners. Over the years, the Ukraine and Belarus have been the victims of "Russian Game" (Shoaib, 2008, 101).

Neutralize the competition: Russia aggressively increase its control over gas pipelines. Moscow has opposed the project that directly connects to the European market to the energy producing countries in Eurasia such as Nabucco project.

Nabucco project is supported by the United States and Europe and challenge the favorite strategy of Russia in Europe. In response Moscow has introduced two major pipeline projects to change the Europe routes of gas: the north and the south streams (drawing strategic / Dymytrva).

South Stream's annual capacity is 30 billion cubic meters of natural gas, bypassing Ukraine and Turkey via the Black Sea to Bulgaria. Gazprom has achieved the Italian gas distribution systems and consumption.

Convergence in foreign level: Moscow is also consolidating its control over oil and gas reserves in the whole of Eurasia, particularly by signing longterm exploration and exploitation agreements with Turkmenistan, Uzbekistan and Kazakhstan to prevent the export of separate agreements with the West. The policy leads to failure the objectives of the European Union for avoiding strategic dependence on Russia and its diversify of the sources of supply. In fact, by buying the produced gas of neighbouring countries the Russians have prevented the creation of a direct link between the regional countries with Europe on the one hand and also to rule out a role as a mediator between the region and Europe. And on the other hand the maintaining its monopoly on energy exports to Europe. While the Russians transfers have gained considerable income by buying gas cheaply and selling it at a higher price in the market (Shoaib, 2007, 102).

Convergence at the local level: Putin's government is trying to establish the government control on the Russian oil and gas sector. The Russian government to exercise control over the country's oil and gas sector, has prevented large international energy companies to access the

Environment Conservation Journal 
Russian energy sector. Oil and gas companies are in a lower tax (kolaee, 2011, 39).

\section{Conclusion}

The purpose of the movements of the US-led NATO in Eastern Europe after the collapse of the Soviet Union, in fact, is to prevent renewal of Russia. At present, the Russian Federation, politically, militarily and economically is far weaker than the Soviet Union and the United States. Politically, Russia does not have a widespread certain ideology as before. In fact, the ideology of the Soviet Union has been forgotten for 20 years. In contrast, we see that American ideology and culture has become pervasive and global with respect to the Russian culture. United States has much more legitimacy with respect to Russia among the global powers. Examples of this issue can be found in the United States attack on Iraq and Afghanistan, it can be observed that most of the western countries have supported The US But the in Ukraine and Crimea crisis to Russia, Europe started a US-led sanction of Russia and turned against it. The US military already accounts for 39 percent of world military spending, China and Russia make up 5.9 and 2.5 percent of the world respectively. Of course the quality of the military budget should be considered, the direction of military spending in China and Russia is for the army and the defense, but the United States is increasing its strike force such as navy. On the other hand Russia has many disputes with the newly independent Republic as well as some internal problems such as Chechnya. Comparing Russia today with the Soviet Union, the Soviet Union had a large number of military bases around the world and its communist ideology was as a paramilitary force arm. In the former Cold War there was an arms race between the two sides and either of them had extended their influence the borders of other side. One specific characteristics of the era was the nature and behavior of political parties, so on one side there was communism and on the other side there was liberalism, within a specified period, from the end of World War II until the collapse of the Soviet Union in 1991. In comparison with the first cold war, the recent cold war is far less severe, with a decline of Russia's superpower to a regional power; it does not have its previous power to advance its goals. The economy of the Russian Federation strongly depends on the revenues from the sale of oil and gas, while the United States has a post-industrial economy. Comparing the Soviet Union that achieved its goal using his military force the Russia uses energy weapon as weapon to proof its characters. One of the issues that need to be addressed is whether or not it is practical to use the energy weapon to put pressure on consumer countries, we should not ignore the fact that the Russian economy is heavily dependent on revenues from energy and wanting to cut their energy constantly for their client states is not reasonable and if this trend continues, countries will turn to other suppliers and will make different routes, unless Russia maintain as a great its force as a greater energy power. In fact, Russia action the political and security use of oil and gas exports, especially to European markets has caused some international analysts to think of the phenomenon of "energy fear" in Europe. The Union of Europe has adopted policies such as diversifying gas imports, variety of the energy portfolio and have turned to limit its economic relations with Moscow. Currently, crude oil prices have fallen sharply and this to the detriment of exporting countries and in favor of energy importing countries. In this conflict, Russia and Europe face the greatest loss, as the United States, have increased its energy security with diverse energy supply, rather than dependence on a unique supplier such as Russia. And it is not unlikely that the Shail Oil project be completed and US will be able to export oil and gas in the future. If the Russia threat for cutting off Europe energy becomes practical, Europe and Russia will be in a very bad condition. However, one of the strategies of Russia is the increased relations with countries opposed to the status quo, i.e., Iran and China. From another perspective, it can be stated that the purpose of US sanctions against Russia, is to put pressure on its revenue source in Ukraine and the conflict in the Middle East and a strategic cooperation with Syria and Iran. 


\section{Russia's energy weapon}

\section{References}

Aghaei.Davood, Samoodi. Allireza, Mousavi, Seyed Mehdi, the US-Russia rivalry and conflict, Autumn 2010, Journal of Political Science and International Relations, Central Tehran Branch, Issue 12.

Behboudi, Davood, Panahi, Hossein, Zamzam, Taghi, The Impact of Sanctions On Iran's Oil And Natural Gas Exportation: SWOT Analysis, The Open Access Journal of Resistive Economics (OAJRE)/ Volume 5, Number 32, 2014.

Bower Mike, Ross, Cameron, Russia after the Cold War, 2000, Pearson Education Limited, England.

British Petroleum statistical review of world energy 2014 full report, 63rd edition, 2015.http://www.bp.com/content/dam/bp/pdf/Energyeconomics/statistical-review-2015/bp-statistical-review-ofworld-energy-2015-full-report.pdf

Cohen, Saul Bernard, geopolitical world order, 2008, translated by Abbas Kardan, Tehran, AbrarMoaser Press.

Ebrahimi, M. (2004), "the strategy of Russia, capacities and actions", Caucasus and Central Asian Studies Quarterly, Year 13, Number 47.

Ebrahimi.Shahrooz, Muhammadi. Mustafa, Russia and the United States compete in the South Caucasus (1991-2010), the summer of 2011, the Central Eurasian Studies, Issue 8.

Haghshenas, MJ, Babir, A, methods of confrontation of Russia with NATO expansion to the East, the fall of 2011, Journal of Political Science and International Relations, Faculty of Political Science, Central Tehran Branch, No. 16.

Irina, Dimitriva, Russia energy diplomacy - EU Europe: Nabucco and South Stream pipelines strategic analysis, translation and MS Sofia NasrollahiJowkar, energy diplomacy, (4).

Kolaee, Elahe, changes in the North Atlantic Treaty Organization's mission and functions, 2007, first edition, Tehran, Tehran University Press.

Kolaee, E, Allah Moradi, A., Russian energy policy in Central Asia, the winter of 2011, the journal Rahbord, 61.
Maleki, Abbas, energy security and the lessons for Iran, Winter 2007, the development strategy (12).

Mazreatti, Mohammed, energy security are two sides of one coin: security of supply and security of demand, the summer of 2007, Energy Economics Studies, No. 13.

Mirfakhraei, SH, Russia and NATO, 2013, first edition, Tehran, Institute for Strategic Studies.

Pasandideh, S, the role of energy in Russian foreign policy, the summer of 2011, Journal of Central Asia and the Caucasus, No. 74.

RamazanZadeh, A., Hosseini SH, the position of Gazprom in Russia's energy strategy, the spring and summer of 2010, the Central Eurasia Studies, Issue 6.

Raquel, Maria (2009) "Russian Politics toward Central Asia: Supporting, Balancing, Coercing or Imposing", A Paper Presented to International Studies Association 50th Annual Convention, 15 - 18 February.

Shoaib. B, the role of energy in the relations between Russia and Europe, Caucasus and Central Asian Studies, Spring 2009, Central Asia and Caucasus Studies, No. 65.

Soovakoul, Benjamin, energy security reference book, 2012, translated by AlirezaTayeb, Tehran.

Terriff, Terry, Drift, Start, Lucy James \& Patrick Morgan, (1998), Security Studies Today, Polity Press, Cambridge, p. 137.

Vaezi Mahmoud, the interests of Russia and the West in Central Asia and the Caucasus, and the role of multilateral organizations, the summer of 2009, Central Asia and Caucasus Studies, No. 66.

Vaezi, Mahmoud, the geopolitical crisis in the Caucasus and Central Asia (founder and actors), 2007, Tehran, Political and International Studies Office of the Ministry of Foreign Affairs

ZareiHadak, Masoomeh, Russian foreign policy toward Europe Union during Putin's presidency, 2012, first edition, Tehran, Ava. 